льотчиків-інструкторів, а також для визначення періодичності проведення тренувальних занять за видами їх професійної підготовки і вибору необхідних методик навчання.

\title{
Література:
}

1. Агапонов И.В., Пономаренко В.А. Управление развитием профессионально важных качеств с целью совершенствования подготовки лётного состава // Авиакосмическая и экологическая медицина. М. : ГосНИИГА, 1992. Т. 26, № 4. С. 14-19.

2. Человеческий фактор // Моделирование деятельности: профессиональная подготовка и отбор операторов. Часть 2. Профессиональная подготовка и отбор операторов. М. : Мир, 1991. T. $3.389 \mathrm{c}$.

3. Макаров Р.Н. Основы формирования профессиональной надёжности лётного состава гражданской авиации: Учебное пособие. М. : Воздушный транспорт, 1990. 384 с.

4. Коваленко Г.В., Крыжановский Г.А. Моделирование в профессиональной подготовке лётного состава гражданской авиации // Итоги науки и техники серия: Воздушный транспорт. М. : ВИНИТИ, 1992. T. 25. 135 c.

5. Бодров В.А. Проблемы профессионального психологического отбора // Психологический журнал. М. : 1985. Вып. 2. С. 20-29.

DOI https://doi.org/10.30525/978-9934-26-146-6-25

\section{БЕЗДРОТОВІ МЕРЕЖЕВІ ТЕХНОЛОГІї В НАВЧАЛЬНОМУ ПРОЦЕСІ}

\section{Слободян С. I.}

завідувачка навчально-методичної лабораторії, викладачка дисииплін професійного ичиллу

Відокремлений структурний підрозділ «Фаховий коледж геологорозвідувальних технологій

Київського начіонального університету імені Тараса Шевченка» м. Київ, Украӥна

В усьому світі стрімко зростає потреба у бездротових з'єднаннях в усіх сферах, адже бездротовий доступ до інформації значно підвищує продуктивність та ефективність роботи. Бездротові мережеві технології 
різняться за масштабом дії їхніх радіосистем, але усі вони з успіхом можуть застосовуватися як у професійній діяльності, так i y повсякденному житті.

Сучасне навчання - це мобільне навчання, 3 швидким доступом до інформаційних, навчально-методичних ресурсів для здобувачів освіти. Такий підхід $\epsilon$ невід'ємною складовою процесу підготовки висококласного фахівця. Тож, широке використання в сучасному освітньому процесі портативних комп'ютерів та багатофункціональних комунікативних електронних пристроїв (мобільні телефони, КПК тощо) актуалізує проблему створення в межах навчального закладу гнучкого робочого середовища. Останне вирізняється вільним доступом у будьякий час і з будь-якого місця до інформаційних ресурсів корпоративної мережі навчального закладу, глобальних інформаційних мереж та їх сервісів. Використання бездротових технологій для вирішення таких задач $є$ досить логічним та обгрунтованим, про що свідчить популярність бездротових мережевих технологій, їх постійний розвиток та вдосконалення.

Важливість використання бездротових мережевих технологій в навчальному процесі зумовлена їх гнучкістю та мобільністю. Такі технології дозволяють здобувачам освіти отримувати доступ до навчально-інформаційних ресурсів закладу освіти та глобальної мережі не лише в спеціально обладнаних аудиторіях, а у будь-якому місці навчального закладу (у навчальних аудиторіях, бібліотеці, читальних залах, місцях відпочинку) та прилеглій до навчального закладу території (якщо це технологічно можливо). Крім цього, наявність в освітній установі локальної бездротової мережі дає можливість самостійно обрати зручний час доступу до потрібної інформації, не підлаштовуючись під робочий розклад «спеціально відведених приміщень».

Сучасні мережеві бездротові технології дозволяють проводити навчальні заняття, інформаційно-просвітницькі заходи у формі відеоконференції без прив'язки до конкретної аудиторії. Для цього при наявності розгалуженої бездротової мережі передачі пакетних даних достатньо лише перенести в потрібну аудиторію комплект устаткування для проведення відеоконференції. Переваги бездротових мережевих технологій, як-то: висока пропускна спроможність та якість передачі даних, уможливлюють їх широке використання. Мобільність бездротових технологій дозволяє досить швидко розгорнути бездротову мережу передачі даних і так само швидко їі згорнути. До того ж, бездротові мережеві технології дозволяють вкрай оперативно реагувати на зміни, які за останній час стали прикметною особливістю освітнього процесу. 
Переваги бездротових мережевих технологій роблять, в свою чергу, менш привабливим використання операторських бездротових мережевих технологій. Як відомо, використання останніх вимагає отримання навчальним закладом обов'язкової ліцензії та дозволу на використання обладнання тієї чи іншої мережевої технології та відповідного частотного діапазону, значних фінансових витрат. Крім цього, операторські бездротові мережеві технології мають низький ступінь мобільності, а клієнтське обладнання є зазвичай доволі громіздким. Безумовно, серед бездротових мережевих технологій операторського класу існують достатньо мобільні та зручні технології, проте низька поширеність мобільних пристроїв, які підтримують такі технології передачі даних, робить ці технології такими, що не є оптимальними для створення бездротової локальної мережі навчального закладу.

Недоліки бездротових мережевих технологій, зокрема незахищеність середовища передачі, не девальвують їх значення для використання у навчальному процесі. Просте підключення абонентів, мобільність, гнучкість і масштабованість мережі - все це дозволяє розглядати такі технології як найбільш оптимальні для створення бездротової локальної мережі навчального закладу.

Отже, активне впровадження та використання сучасних інформаційних технологій в навчальний процес $\epsilon$ неодмінною умовою підвищення якості освіти, що є пріоритетним напрямом державної освітньої політики. Вагому роль для забезпечення якості освіти відіграє створення локальної мережі навчального закладу на основі бездротових мережевих технологій.

\section{Література:}

1. HiperLAN. From Wikipedia, the free encyclopedia http://en.wikipedia.org/wiki/HIPERLAN

2. Очередная борьба стандартов: HiperLAN2 и IEEE 802.11. CNews. http://www.cnews.ru/reviews/index.shtml?2000/04/07/99530

3. Quality of Service - Матеріал з Вікіпедії - вільної енциклопедії. http://uk.wikipedia.org/wiki/QoS

4. ZigBee specification. ZigBee Document 053474r06, Version 1.0. 2005. http://www.zigbee.org/

5. Опыт построения сети беспроводных датчиков для мониторинга систем ОВК зданий // АВОК. 2009. № 1.

6. Bluetooth specification, Version 2.0 + EDR. 2011. // http://www.bluetooth.com/

7. WiFi specification. 2006. http://www.wifi.com/p_faq.html. 